\title{
DETERMINANTS OF DENGUE HEMORRHAGIC FEVER OUTBREAK IN CIPAYUNG, EAST JAKARTA
}

\author{
Cicilia Windiyaningsih, Tiwi Nurhastuti \\ Respati University, Indonesia
}

\begin{abstract}
Background: Dengue hemorrhagic fever (DHF) is an infectious disease that is caused by dengue virus. To date no specific medicine is available for this disease. Jakarta Province ranks $5^{\text {th }}$ in the incidence of DHF. In 2014, the cumulative incidence (CI) of DHF was 48.7 cases/100,000. In Cipayung sub district (East Jakarta), there were 136 new cases of DHF (CI= 52.1/100.000) in 2015. This study aimed to investigate the determinants of DHF outbreak in Cipayung, East Jakarta.

Subjects and Method: This was a cross-sectional study, conducted in Cipayung, East Jakarta. A sample of 594 households were selected at random for this study. The dependent variable was DHF. The independent variables were dweller density, water container drainage, container supervision. The data were collected using questionnaire and observation. The data was analyzed by multiple logistic regression.

Results: DHF incidence was affected by container supervision $<1$ time per week $(\mathrm{OR}=2.45 ; 95 \% \mathrm{CI}=1.57$ to $3.84 ; \mathrm{p}<0.001)$, container drainage $<4$ times/month $(\mathrm{OR}=1.82 ; 95 \% \mathrm{CI}=1.19$ to $2.79 ; \mathrm{p}=0.006)$, dweller density $<4$ $(\mathrm{OR}=0.61 ; 95 \% \mathrm{CI}=0.42$ to $0.87 ; \mathrm{p}=0.007)$.
\end{abstract}

Conclusion: DHF incidence is affected by container supervision $<1$ time per week, container drainage $<4$ times/month, dweller density $<4$.

Keywords: DHF, container drainage, container supervision, dweller density

Correspondence: Cicilia Windiyaningsih. Respati University, Indonesia. Email: sisilwindi@gmail.com. Mobile: +628113873428. 